\title{
PENERAPAN MODEL PEMBELAJARAN INTERAKTIF DENGAN MEDIA MINIATUR UNTUK PENINGKATAN HASIL BELAJAR IPA SEKOLAH DASAR
}

\author{
Bayu Widiyanto \\ Institut Agama Islam Syarifuddin Lumajang, Indonesia \\ Email : bayuwidiyanto12@gmail.com
}

\begin{abstract}
IPA merupakan mata pelajaran yang mempelajari sebab-akibat dari kejadian yang terjadi di alam ini, pembelajaran IPA melibatkan siswa berperan aktif dalam menemukan konsep. Sehingga diperlukan model pembelajaran dan media pembelajaran yang dapat memudahkan siswa dalam menemukan sebuah konsep. Media miniature merupakan media pembelajaran yang dapat digunakan dalam pembelajaran untuk siswa memahami konsep. Penelitian ini bertujuan untuk mengetahui peningkatan hasil belajar siswa dengan menggunakan Model pembelajaran interaktif tentang pengelompkan hewan. Penelitian ini adalah penelitian tindakan kelas menggunakan model Kemmis \& Mc Taggart. Dalam penelitian ini, pengukuran diperlakukan dengan lembar aktivitas siswa dan dalam waktu tertentu diberikan posttest. Subjek penelitian ini adalah siswa kelas tiga SDN Kemuning Lor 02 Jember
\end{abstract}

Kata Kunci : IPA, Media Miniatur, Model Interaktif

\section{Pendahuluan}

Pengalaman belajar yang diterima siswa di sesuaikan dengan prinsip belajar sepanjang hidup yang mengacu pada empat pilar Pendidikan yaitu belajar untuk mengetahui (learning to know), belajar dengan melakukan (learning to do), belajar untuk hidup dalam kebersamaan (learning to live together), dan belajar menjadi diri sendiri (learning to be). Untuk itu diperlukan suatu upaya dalam meningkatkan kualitas pembelajaran dengan membimbing siswa telibat aktif dalam proses pembelajaran dan membantu siswa berkembang dengan taraf 
intelektualnya, yang akan lebih menguatkan pemahaman siswa terhadap konsep-konsep yang diajarkan.

Salah satu mata palajaran yang diajarkan pada tingkat SD/MI adalah ilmu pengetahuan alam (IPA). Dalam pembelajaran IPA, siswa dapat mempelajari sebab-akibat dari kejadian yang terjadi di alam ini. Dalam pandangan konstruktivisme keberhasilan pembelajaran bergantung bukan hanya pada lingkungan atau kondisi belajar, akan tetapi juga pada pengetahuan awal siswa. Belajar melibatkan pembentukan "makna" oleh siswa dari apa yang mereka lakukan, lihat, dan dengar. ${ }^{1}$ pembelajaran IPA melibatkan siswa berperan aktif dalam menemukan konsep.

Penggunaan media miniatur atau media tiga dimensi dalam pembelajaran IPA merupakan salah satu cara dalam menggantikan media pembelajaran nyata kepada siswa dalam pembelajaran. Benda tiruan seperti benda tiga dimendi yang bias disentuh dan diraba dapat memantu siswa memahami konsep materi yang diberkan guru dalam pembelajaran. ${ }^{2}$ Media ini dibuat untuk mengatasi keterbatasan baik objek maupun situasi sehingga proses pelajaran dapat berjalan dnegan baik. ${ }^{3}$

Proses pembelajaran memerlukan model pembelajaran yang mampu membantu anak didik memahami materi yang dipelajari sekaligus melatih siswa untuk memecahkan masalah yang diperolehnya sekaligus memunculkan sikap mandiri dalam belajar. Model pembelajaran interaktif merupakan model pembelajaran yuang menekankan pada ketrampilan bertanya anak. Model ini dirancang agar siswa akan bertanya dan kemudian menemukan jawaban pertanyaan mereka sendiri. ${ }^{4}$

\footnotetext{
1 West \& Pines dan Sutarno, N. Materi dan Pembelajaran IPA SD. Jakarta: Universitas Terbuka, 2009.

2 Evi Fatimatur Rusydiyah, Media Pembelajaran (Implementasi untuk Anak di Madrasah Ibtidaiyah), UIN Sunan Ampel Surabaya, 2015.

${ }^{3}$ Abdillah, Media Pembelajaran dan Jenis-jenisnya. [ Serial Online] , 2011, http:/ /ilmumahasiswa.com/media-pembelajaran-dan-jenis-jenisnya/ (diakses tanggal 7 April 2019)

4 Sutarno, Materi dan pembelajaran, 2009.
} 
Pembelajaran interaktif membantu guru mengambil langkah khusus untuk mengumpulkan, memilah, dan mengubah sebuah pertanyaan sehingga terbentuk suatu struktur pembelajaran IPA. ${ }^{5}$

Menyadari pentingnya menggunaan media dan model pembelajaran yang tepat dalam pembelajaran IPA, maka peneliti menerapkan model pembelajaran interaktif dengan media miniatur untuk peningkatan hasil belajar ipa pada siswa sekolah dasar.

\section{Tinjauan Pustaka}

\section{Pembelajaran IPA SD}

IPA merupakan usaha manusia dalam memahami alam semesta melalui pengamatan yang tepat (correct) pada sasaran, serta menggunakan prosedur yang benar (true), dan dijelaskan dengan penalaran yang sahih (valid) sehingga dihasilkan kesimpulan yang benar (truth). ${ }^{6}$ IPA mengandung tiga hal yaitu: proses (usaha peserta didik memahami alam semesta), prosedur (pengamatan yang tepat dan prosedur yang benar) dan produk (kesimpulannya benar). Mengajar IPA tidak terbatas pada produk atau fakta, konsep, dan teori saja karena dalam mengajar IPA belum lengkap jika hanya mengajarkan salah satu komponen saja. IPA dapat dikatakan ilmu pengetahuan yang tersusun teratur tentang alam dan materi yang pada umumnya didasarkan atas pengamatan.

\section{Model Pembelajaran}

Menurut Soekamto dan Winataputra model adalah suatu kerangka konseptual yang digunakan sebagai pedoman di dalam melakukan suatu kegiatan. ${ }^{7}$ Model adalah suatu deskripsi atau analogi yang digunakan

\footnotetext{
${ }^{5}$ Sulastri, Meningkatkan Prestasi Belajar Siswa Melalui Model Pembelajaran Interaktif Pada Pokok Bahasan Konduktor Dan Isolator, 2015, Jurnal Serambi Ilmu, Volume 22 Nomor 1.

'Sutrisno. Pengembangan Pembelajaran IPA SD (Diktat Kuliah). Jakarta :Universitas terbuka. 2008.

7 Feni Normawati, Meningkatkan Keaktifan Peserta Didik dalam Proses Pembelajaran Dengan Menggunakan Model Pembelajaran Make A Match (Membuat Pasangan).
} 
untuk memperlihatkan dalam bentuk yang sederhana sesuatu yang sukar untuk diamati. ${ }^{8}$ Selanjutnya, menurut Saripuddin bahwa model pembelajaran adalah sebagai kerangka konseptual yang menggambarkan prosedur yang sistematis dalam mengorganisasikan pengalaman belajar untuk mencapai tujuan belajar tertentu, dan berfungsi sebagai pedoman bagi perancang pembelajaran dan para pengajar dalam merencanakan dan melaksanakan kegiatan aktivitas belajar mengajar. ${ }^{9}$

Joice dan Weil mengelompokkan model-model pembelajaran ke dalam empat kategori, yakni: (a) kelompok model pengolahan informasi atau the information processing family, bahwa seseorang dapat mengetahui informasi dengan cara menggali dan mengorganisasikan data serta berusaha memecahkan suatu permasalahan; (b) kelompok model personal atau the personal family, kelompok model ini memusatkan perhatian pada pandangan seseorang dan berusaha menggalakkan kemandirian; (c) kelompok model sosial atau the social family, kelompok model ini menitikberatkan pada kemampuan untuk bekerjasama; (d) kelompok model sistem perilaku atau the behavioral system family, memusatkan perhatian pada perilaku yang terobservasi. ${ }^{10}$

Joyce dan Weil dalam Winataputra mengatakan bahwa setiap model pembelajaran memiliki unsur-unsur sebagai berikut:

1) sintakmatik, ialah tahap-tahap kegiatan dari model;

skripsi, FKIP UNPAS, 2016. http://repository.unpas.ac.id/11297/(diakses pada 12 Januari 2019)

${ }^{8}$ Roestiyah, N.K. Masalah Pengajaran sebagai Suatu Sistem. Jakarta : PT Rieneka Cipta. 1994. ${ }^{9}$ Novitangatus Sangadah, Pengaruh Model Pembelajaran Active Learning Tipe Card Sort Terhadap Hasil Belajar Fiqih Siswa Kelas Viii Di MTSN 2 Tulungagung, Skripsi, IAIN Tulungagung, 2019, http://repo.iain-tulungagung.ac.id/12733/ diakses pada (22 januari 2019)

${ }^{10}$ Elvi Sukesih, Efektivitas Penerapan Model Pembelajaran Berbasis Proyek Terhadap Hasil Belajar Siswa Pada Mata Pelajaran TIK Pokok Bahasan Penggunaan Dasar Internet/Intranet Di SMP N 1 Kaliwungu, Under Graduates thesis, Universitas Negeri Semarang. 2015. diakses pada (22 januari 2019) 
2) sistem sosial, ialah situasi atau suasana dan norma yang berlaku dalam model;

3) prinsip reaksi, ialah pola kegiatan yang menggambarkan bagaimana seharusnya guru melihat dan memperlakukan para pelajar, termasuk bagaimana seharusnya pengajar memberikan respon terhadap siswa;

4) sistem pendukung, ialah segala sarana, bahan, dan alat yang diperlukan untuk melaksanakan model;

5) dampak instruksional, ialah hasil belajar yang dicapai langsung dengan cara mengarahkan para pelajar pada tujuan yang diharapkan;

6) dampak pengiring, ialah hasil belajar lainnya yang dihasilkan oleh proses pembelajaran, sebagai akibat terciptanya suasana belajar yang dialami langsung oleh para pelajar tanpa pengarahan langsung dari pengajar.

\section{Model Pembelajaran Interaktif}

Interaktif didefinisikan sebagai "kemampuan sistem/program yang bisa menanyakan sesuatu pada pengguna (mengadakan tanya jawab), kemudian mengambil tindakan berdasarkan respon tersebut."11

Menurut Faire \& Cosgrove dalam Harlen model pembelajaran interaktif sering dikenal dengan nama pendekatan pertanyaan anak. Model ini dirancang agar siswa akan bertanya dan kemudian menemukan jawaban pertanyaan mereka sendiri. ${ }^{12}$ Menurut Harlen, meskipun anak-anak mengajukan pertanyaan dalam kegiatan bebas, pertanyaan-pertanyaan tersebut akan terlalu melebar dan seringkali kabur sehingga kurang terfokus. Guru perlu mengambil langkah khusus untuk mengumpulkan, memilah, dan mengubah pertanyaan-pertanyaan tersebut ke dalam kegiatan khusus. Pembelajaran interaktif merinci

${ }^{11}$ https://kbbi.kemdikbud.go.id/

12 Sutarno, Materi dan pembelajaran, 2009. 
langkah-langkah ini dan menampilkan suatu struktur untuk suatu pelajaran IPA yang melibatkan pengumpulan dan pertimbangan terhadap pertanyaan-pertanyaan siswa sebagai pusatnya. ${ }^{13}$

Model pembelajaran interaktif memiliki lima langkah, langkahlangkah pembelajaran interaktif adalah sebagai berikut:

Table 2.1 Langkah-Langkah Pembelajaran Interaktif

\begin{tabular}{|c|c|c|}
\hline No & $\begin{array}{l}\text { Langkah-Langkah } \\
\text { Pembelajaran }\end{array}$ & Jenis Kegiatan Belajar Mengajar \\
\hline 1 & Persiapan & $\begin{array}{l}\text { a. Mencari sumber-sumber informasi } \\
\text { tentang makhluk hidup. } \\
\text { b. Mempersiapkan bahan-bahan } \\
\text { pembelajaran }\end{array}$ \\
\hline 2 & Kegiatan penjelajahan & $\begin{array}{l}\text { a. Pembagian LKS, media, dan materi } \\
\text { b. Penyajikan masalah }\end{array}$ \\
\hline 3 & Pertanyaan anak & $\begin{array}{l}\text { a. Membimbing dan mengarahkan } \\
\text { siswa untuk bertanya. } \\
\text { b. menulis pertanyaan-pertanyaan (di } \\
\text { papan tulis) } \\
\text { c. Pemilih pertanyaan-pertanyaan } \\
\text { yang ingin diketahui jawabannya } \\
\text { melalui penyelidikan. }\end{array}$ \\
\hline 4 & Penyelidikan & $\begin{array}{l}\text { a. Menentukan urutan pertanyaan } \\
\text { yang ingin diketahui jawabannya } \\
\text { melalui penyelidikan. } \\
\text { b. membimbing kelompok-kelompok } \\
\text { dalam melakukan penyelidikan. }\end{array}$ \\
\hline 5 & Refleksi & $\begin{array}{lr}\text { mendiskusikan } & \text { hasil } \\
\text { penyelidikannya } & \text { dan } \\
\text { membandingkannya } & \text { dengan } \\
\text { jawaban pada pengetahuan awal. }\end{array}$ \\
\hline
\end{tabular}

Model Pembelajaran Interaktif mempunyai karakteristik umum sebagai berikut :

1) adanya variasi kegiatan klasikal, kelompok dan perseorangan.

2) keterlibatan mental (berpikir dan perasaan) siswa tinggi.

3) guru lebih berperan sebagai fasilitator, narasumber, dan manajer kelas yang demokratis.

13 Sutarno, Materi dan pembelajaran, 2009. 
4) menerapkan pola komunikasi banyak arah.

5) suasana kelas yang fleksibel, demokratis, menantang, dan tetap terkendali oleh tujuan.

6) pontensial dapat menghasilkan dampak intruksional dampak pengiring lebih efektif.

7) dapat digunakan didalam maupun diluar kelas

\section{Media Pembelajaran}

Kata media merupakan bentuk jamak dari medium. Kata itu berasal dari bahasa latin "medius" yang artinya tengah. Dalam kamus bahasa Indonesia, kata medium artinya antara. Secara harfiah kata media berarti perantara atau pengantar.

Beberapa ahli memberikan definisi tentang media pembelajaran. Briggs berpendapat bahwa media pembelajaran adalah sarana fisik untuk menyampaikan isi/materi pembelajaran, seperti: buku, film, video, dan sebagainya. ${ }^{14}$ Sedangkan menurut National Education Association mengungkapkan bahwa media pembelajaran adalah sarana komunikasi dalam bentuk cetak maupun pandang-dengar, termasuk teknologi perangkat keras. ${ }^{15}$

Secara lebih khusus, pengertian media dalam proses pembelajaran cenderung diartikan sebagai alat-alat grafis, photografis, atau elektronis untuk menangkap, memproses, dan menyusun kembali informasi visual atau verbal. ${ }^{16}$ Menurut Rohani media adalah segala sesuatu yang dapat diindra yang berfungsi sebagai perantara/sarana/alat untuk memproses komunikasi (proses pembelajaran). ${ }^{17}$

\footnotetext{
${ }^{14}$ Tri Karyanti, dkk. Pendidikan Anti Korupsi Berbasis Multimedia, Yogyakarta:Deepublish, 2019.

${ }^{15}$ Rusman, Belajar \& Pembelajaran: Berorientasi Standar Proses Pendidikan, Jakarta:Kencana.2017.

${ }^{16}$ Budiyanto, Arifin, Pengembangan Media Pembelajaran Pendidikan Agama Islam (PAI) Di SMP Raudlatul Jannah Waru Sidoarjo, tesis, UIN Sunan Ampel Surabaya. 2014, ${ }^{17}$ Isran Rasyid Karo-Karo S dan Rohani, Manfaat Media Dalam Pembelajaran, Jurnal AXIOM: Vol. VII, No. 1, Universitas Islam Sumatera Utara Medan, 2018.
} 
Menurut Sadiman dkk media adalah perantara atau pengantar pesan dari pengirim ke penerima pesan. ${ }^{18}$ Menurut Danim media pendidikan (pembelajaran) merupakan alat bantu atau pelengkap yang digunakan oleh guru atau pendidik dalam rangka berkomunikasi dengan siswa atau peserta didik. ${ }^{19}$ Sedangkan menurut Hamalik, media pendidikan (pembelajaran) adalah alat, metode, dan teknik yang digunakan dalam rangka lebih mengefektifkan komunikasi dan interaksi antara guru dengan siswa dalam proses pendidikan dan pengajaran di sekolah. ${ }^{20}$

\section{Media Miniatur}

Media miniatur adalah media yang hanya dapat dilihat, yang termasuk kelompok visual, seperti foto, gambar, poster, grafik, kartun, liflet, buklet, torso, film bisu, model 3 dimensi seperti diorama dan mokeup.

Menurut Heinich dan Molenda bahwa benda-benda tiruan/miniatur seperti benda-benda tiga dimensi yang bisa disentuh dan diraba oleh siswa dapat membantu siswa memahami konsep materi yang diberikan guru dalam pembelajaran. ${ }^{21}$ Media ini dibuat untuk mengatasi keterbatasan baik objek maupun situasi sehingga proses pelajaran dapat berjalan dengan baik. ${ }^{22}$

Kelompok media ini dapat berwujud sebagai benda asli baik hidup maupun mati, dan dapat pula berwujud sebagai tiruan yang mewakili aslinya. Benda asli ketika akan difungsikan sebagai media pembelajaran

\footnotetext{
${ }^{18}$ Husniyatus Salamah Zainiyati, Pengembangan Media Pembelajaran Agama Islam Berbasis ICT, Jakarta:Penerbit Kencana, 2017.

${ }^{19}$ Umar, Media Pendidikan: Peran dan Fungsinya dalam Pembelajaran, Jurnal Tarbawiyah Volume 11 Nomor 1, IAIN Metro, 2014.

${ }^{20}$ Wijayanti Meliana , Pengembangan Media Pembelajaran Membaca Titi Laras Tembang Macapat Dhandhanggula Menggunakan Aplikasi Adobe Flash CS5 Untuk Siswa Smp Kelas Viii, tesis, Universitas Negeri Yogyakarta, 2012.

${ }^{21}$ Arsyi Nurfadillah, Penggunaan Media Komik Untuk Meningkatkan Keterampilan Berkomunikasi Dan Hasil Belajar Siswa Kelas IV Tema Indahnya Kebersamaan Subtema Keberagaman Budaya Bangsaku, thesis, FKIP UNPAS. 2018. http://repository.unpas.ac.id/39513/

${ }^{22}$ Abdillah, Media Pembelajaran, 2011.
} 
dapat dibawa langsung ke kelas, atau siswa sekelas dikerahkan langsung ke dunia sesungguhnya di mana benda asli itu berada. Apabila benda aslinya sulit untuk dibawa ke kelas atau kelas tidak mungkin dihadapkan langsung ke tempat di mana benda itu berada, maka benda tiruannya dapat pula berfungsi sebagai media pembelajaran yang efektif. Media tiga dimensi yang dapat diproduksi dengan mudah adalah tergolong media sederhana dalam penggunaan dan pemanfaatannya, karena tanpa harus memerlukan keahlian khusus, dapat dibuat sendiri oleh guru, bahannya mudah diperoleh di lingkungan sekitar.

Moedjiono mengatakan bahwa media sederhana tiga dimensi memiliki kelebihan-kelebihan, yaitu memberikan pengalaman secara langsung, penyajian secara kongkrit dan menghindari verbalisme, dapat menunjukkan obyek secara utuh baik konstruksi maupun cara kerjanya, dapat memperlihatkan struktur organisasi secara jelas, dapat menunjukkan alur suatu proses secara jelas. ${ }^{23}$ Sedangkan kelemahankelemahannya yaitu tidak bisa menjangkau sasaran dalam jumlah yang besar, penyimpanannya memerlukan ruang yang besar dan perawatannya rumit. Namun kelemahan tersebut dapat diatasi, misalnya membentuk pembelajaran dengan kelompok sehingga dapat menjangkau sasaran, dan dalam proses penyimpanannya disediakan ruangan khusus.

\section{Metode Penelitian}

Desain penelitian yang digunakan dalam penelitian ini adalah model penelitian Kemmis \& Mc Taggart yang terdiri dari perencanaan, tindakan, observasi, dan refleksi. ${ }^{24}$

\footnotetext{
${ }^{23}$ Frieda Dewi Kusumawati dan Ika Priantari, Metode Demonstrasi Dengan Media Tiga Dan Dua Dimensi Terhadap Hasil Belajar Siswa Demonstration Method With Media Three And Two Dimensional Through Student Achievement, Jurnal Pendidikan Biologi FKIP Universitas Muhammadiyah Jember, 2016.

${ }^{24}$ Nining Pontiani, Penerapan Metode Make A Match Untuk Meningkatkan Hasil Belajar Ilmu Pengetahuan Sosial (Ips) Siswa Kelas Iii Mi Tarbiyatul Banin Walbanat Kedungsigit Karangan Trenggalek, Fakultas Tarbiyah Dan Ilmu Keguruan Institut Agama Islam Negeri (Iain) Tulungagung, 2015.
} 
Analisis data menggunakan Teknik untuk menentukan besar ketuntasan hasil belajar setelah pembelajaran menggunakan model interaktif berdasarkna rumus klasikal.

$$
P=\frac{n}{N} \times 100 \%
$$

Keterangan :

$\mathrm{P}=$ persentase ketuntasan belajar siswa

$\mathrm{n}=$ jumlah siswa yang tuntas belajar

$\mathrm{N}=$ jumlah seluruh siswa

Tabel 1. Kriteria Ketuntasan Hasil Belajar

\begin{tabular}{ccc}
\hline No & Persentase Ketuntasan hasil belajar & Kriteria \\
\hline 1 & $91 \% \leq \mathrm{P} \leq 100 \%$ & Sangat tuntas \\
2 & $80 \% \leq \mathrm{P} \leq 90 \%$ & Tuntas \\
3 & $\mathrm{P}<79 \%$ & Tidak Tuntas \\
\end{tabular}

Kriteria ketuntasan suatu kelas di SDN Kemuning Lor 02 Jember dikatakan tuntas apabila terdapat $\geq 80 \%$ dari keseluruhan siswa yang mendapat skor $\geq 60$ dari skor maksimal 100 .

Table 2. Kriteria Penilaian Hasil Belajar Siswa

\begin{tabular}{cc}
\hline Kriteria Nilai & Kualifikasi Hasil \\
\hline $70 \leq$ & Sangat baik \\
$60-69$ & Baik \\
$50-59$ & Cukup \\
$40-49$ & Kurang \\
$\leq 39$ & Sangat kurang
\end{tabular}

\section{(Purwanto, 2001)}

Kriteria ketuntasan hasil belajar siswa SDN Kemuning Lor 02 Jember pada mata pelajaran IPA yang digunakan dalam penelitian ini yaitu dengan syarat ketuntasan belajar minimal (SKBM) adalah siswa mendapatkan skor $\geq 60$ dari skor maksimal 100 yang diperoleh setiap siswa. 


\section{Hasil dan Pembahasan}

Hasil

Ketuntasan hasil belajar kognitif siswa pada penelitian ini mengalami peningkatan. Hal itu dapat dilihat dari ketuntasan ketuntasan hasil belajar siswa yang ditunjukkan pada tabel 4.10 berikut ini :

Tabel 3. Perbandingan Hasil Belajar Kognitif Siklus 1 dan siklus 2

\begin{tabular}{lccc}
\multicolumn{1}{c}{ Kriteria Hasil Belajar } & Siklus I & Siklus & Selisih \\
& & II & \\
& $(\%)$ & $(\%)$ & $(\%)$ \\
Sangat baik & 13,33 & 23,33 & 10 \\
Baik & 26,66 & 36,66 & 10 \\
Cukup & 26,66 & 26,66 & 0 \\
Kurang & 20 & 6,66 & $-13,34$ \\
Sangat kurang & 13,33 & 6,66 & $-6,67$ \\
\hline Total & 100 & 100 & 0 \\
\hline
\end{tabular}

Tabel perbandingan hasil belajar kognitif siswa siklus 1 dan siklus 2 di atas, diketahui bahwa hasil belajar siswa yang tergolong dalam kriteria sangat baik pada siklus 1 sebesar 13,33\% sedangkan pada siklus 2 mencapai 23,33\% dengan demikian kriteria hasil belajar siswa yang tergolong sangat baik mengalami peningkatan sebesar 10\%. Hasil belajar siswa yang tergolong dalam kriteria baik pada siklus 1 sebesar 26,66\% sedangkan pada siklus 2 juga sebesar 36,66\% dengan demikian kriteria hasil belajar siswa yang tergolong baik mengalami peningkatan sebesar $10 \%$. Hasil belajar siswa yang tergolong dalam kriteria cukup baik pada siklus 1 sebesar 26,66\% sedangkan pada siklus 2 sebesar 26,66\% dengan demikian kriteria hasil belajar siswa yang tergolong cukup baik tidak mengalami kenaikan atau penurunan (tetap).

Hasil belajar siswa yang tergolong dalam kriteria kurang baik pada siklus 1 sebesar 20\% sedangkan pada siklus 2 sebesar 6,66 dengan demikian kriteria hasil belajar siswa yang tergolong kurang baik mengalami penurunan sebesar 13,34\%. Hasil belajar siswa yang 
tergolong dalam kriteria sangat kurang pada siklus 1 sebesar 13,33\% sedangkan pada siklus 2 sebesar 6,66\% sehingga dapat disimpulkan bahwa kriteria hasil belajar kognitif siswa yang tergolong sangat kurang mengalami penurunan sebesar $6,67 \%$, untuk lebih jelasnya dapat dilihat pada diagram berikut ini.

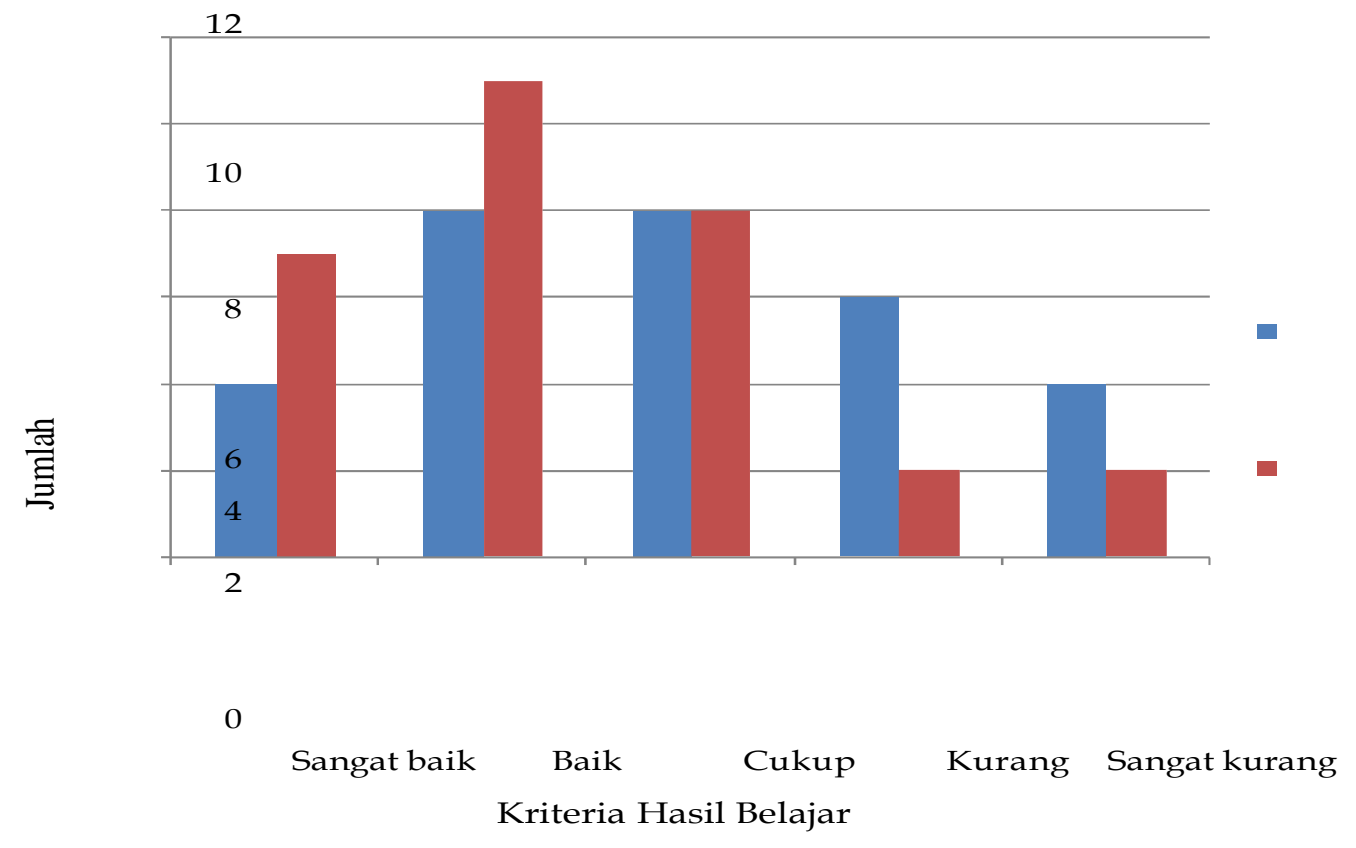

Gambar 1. Diagram Peningkatan Hasil Belajar Kognitif Siswa Siklus 1 dan Siklus 2

Persentase hasil belajar kognitif siswa secara klasikal pada siklus 1 sebesar 66,66\% (lampiran I.1) sedangkan persentase hasil belajar kognitif siswa secara klasikal pada siklus 2 mencapai 86,66\% (lampiran I.4) dengan demikian dapat diketahui bahwa persentase hasil belajar siswa secara klasikal juga mengalami peningkatan sebesar $20 \%$.

Selain itu ketuntasan hasil belajar afektif siswa juga mengalami peningkatan. Hal itu dapat dilihat dari ketuntasan ketuntasan hasil belajar siswa yang ditunjukkan pada tabel 4 berikut ini : 
Tabel 4. Perbandingan Hasil Belajar Afektif Siklus 1 dan Siklus 2

\begin{tabular}{lccc}
\hline \multicolumn{1}{c}{ Kriteria Hasil Belajar } & $\begin{array}{c}\text { Siklus I } \\
(\%)\end{array}$ & $\begin{array}{c}\text { Siklus II } \\
(\%)\end{array}$ & $\begin{array}{c}\text { Selisih } \\
(\%)\end{array}$ \\
\hline Sangat baik & 16,7 & 43,3 & 26,6 \\
Baik & 26,6 & 20 & $-6,6$ \\
Cukup & 30 & 23,3 & $-6,7$ \\
Kurang & 13,3 & 13,3 & 0 \\
Sangat kurang & 13,3 & 0 & $-13,3$ \\
\hline Total & 100 & 100 & 0 \\
\hline
\end{tabular}

Tabel perbandingan hasil belajar afektif siswa siklus 1 dan siklus 2 di atas, diketahui bahwa hasil belajar siswa yang tergolong dalam kriteria sangat baik pada siklus 1 sebesar 16,6\% sedangkan pada siklus 2 mencapai 43,3\% dengan demikian kriteria hasil belajar siswa yang tergolong sangat baik mengalami peningkatan sebesar 26,6\%. Hasil belajar siswa yang tergolong dalam kriteria baik pada siklus 1 sebesar 26,6\% sedangkan pada siklus 2 sebesar 20\% dengan demikian kriteria hasil belajar siswa yang tergolong baik mengalami penurunan sebesar 6,6\%. Hasil belajar siswa yang tergolong dalam kriteria cukup pada siklus 1 sebesar $30 \%$ sedangkan pada siklus 2 sebesar 23,3\% dengan demikian kriteria hasil belajar siswa yang tergolong baik mengalami penurunan sebesar 6,7\% . Hasil belajar siswa yang tergolong dalam kriteria kurang baik pada siklus 1 sebesar 13,3\% sedangkan pada siklus 2 sebesar 13,3\% dengan demikian kriteria hasil belajar siswa yang tergolong kurang baik tidak mengalami peningkatan dan penurunan (tetap).

Hasil belajar siswa yang tergolong dalam kriteria sangat kurang pada siklus 1 sebesar 13,3\% sedangkan pada siklus 2 sebesar $0 \%$ dengan demikian kriteria hasil belajar siswa yang tergolong baik mengalami penurunan sebesar 13,3\%. Sehingga dapat disimpulkan bahwa kriteria hasil belajar afektif siswa yang tergolong kurang mengalami penurunan 
sebesar $13,3 \%$, untuk lebih jelasnya dapat dilihat pada diagram berikut ini.

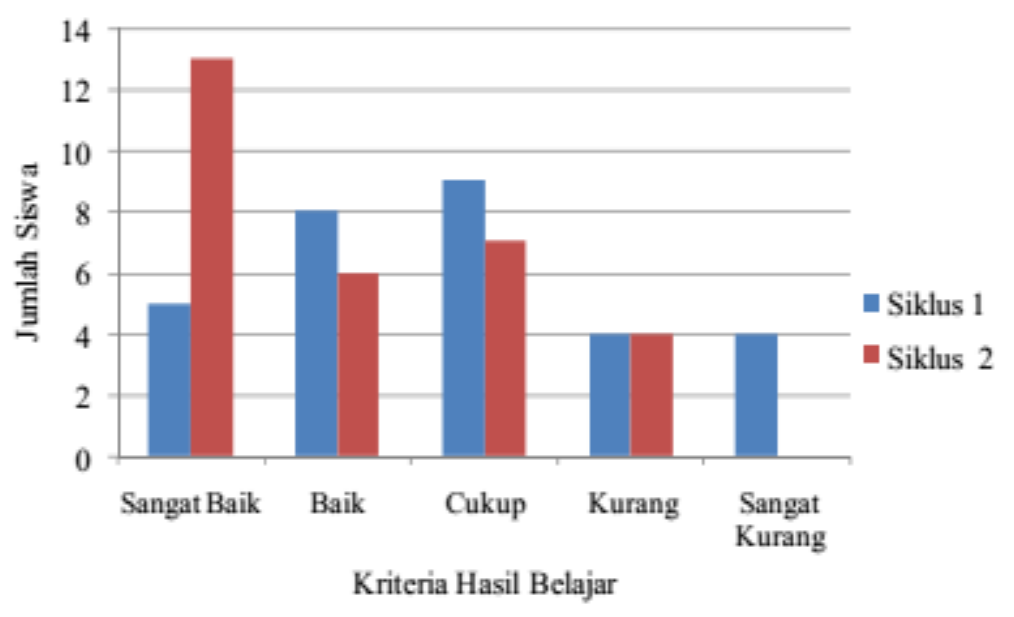

Gambar 2. Diagram Peningkatan Hasil Belajar Afektif Siswa Siklus 1 dan Siklus 2

Persentase hasil belajar afektif siswa secara klasikal pada siklus 1 sebesar 73,3\% (lampiran I.2) sedangkan persentase hasil belajar afektif siswa secara klasikal pada siklus 2 mencapai 86,6\% (lampiran I.5) dengan demikian dapat diketahui bahwa persentase hasil belajar siswa secara klasikal juga mengalami peningkatan sebesar 13,3\%.

Sedangkan ketuntasan hasil belajar psikomotor siswa juga mengalami peningkatan. Hal itu dapat dilihat dari ketuntasan ketuntasan hasil belajar siswa yang ditunjukkan pada tabel 5 berikut ini :

Tabel 5. Perbandingan Hasil Belajar Psikomotor Siklus 1 dan Siklus 2

\begin{tabular}{lccc}
\multicolumn{1}{c}{ Kriteria Hasil Belajar } & $\begin{array}{c}\text { SIKIus I } \\
(\%)\end{array}$ & $\begin{array}{c}\text { Siklus II } \\
(\%)\end{array}$ & $\begin{array}{c}\text { Selisih } \\
(\%)\end{array}$ \\
Sangat baik & 30 & 40 & 10 \\
Baik & 20 & 26,7 & 6,7 \\
Cukup & 20 & 16,7 & $-3,3$ \\
Kurang & 13,3 & 10 & -3.3 \\
Sangat kurang & 16,7 & 6,6 & $-10,1$ \\
\hline
\end{tabular}


Tabel perbandingan hasil belajar psikomotor siswa siklus 1 dan siklus 2 di atas, diketahui bahwa hasil belajar siswa yang tergolong dalam kriteria sangat baik pada siklus 1 sebesar 30\% sedangkan pada siklus 2 mencapai $40 \%$ dengan demikian kriteria hasil belajar siswa yang tergolong sangat baik mengalami peningkatan 10\%. Hasil belajar siswa yang tergolong dalam kriteria baik pada siklus 1 sebesar 20\% sedangkan pada siklus 2 sebesar 26,6\% dengan demikian kriteria hasil belajar siswa yang tergolong baik mengalami peningkatan sebesar $6,7 \%$. Hasil belajar siswa yang tergolong dalam kriteria cukup pada siklus 1 sebesar $20 \%$ sedangkan pada siklus 2 sebesar 16,7\% dengan demikian kriteria hasil belajar siswa yang tergolong baik mengalami penurunan sebesar 3,3\%. Hasil belajar siswa yang tergolong dalam kriteria kurang baik pada siklus 1 sebesar 13,2\% sedangkan pada siklus 2 sebesar 10\% dengan demikian kriteria hasil belajar siswa yang tergolong kurang baik penurunan sebesar 3,3\%. Hasil belajar siswa yang tergolong dalam kriteria sangat kurang pada siklus 1 sebesar 16,7\% sedangkan pada siklus 2 sebesar 6,6\% dengan demikian kriteria hasil belajar siswa yang tergolong baik mengalami penurunan sebesar 10,1\%. Sehingga dapat disimpulkan bahwa kriteria hasil belajar psikomotor siswa yang tergolong kurang mengalami penurunan sebesar 13,4\%, untuk lebih jelasnya dapat dilihat pada diagram berikut ini.

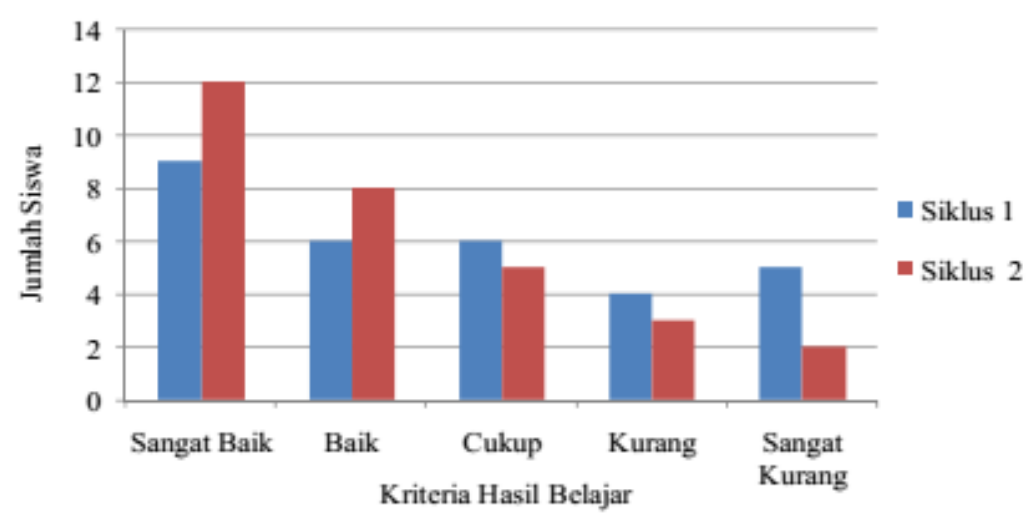

Gambar 3. Diagram Peningkatan Hasil Belajar Psikomotorik Siswa Siklus 1 dan Siklus 2 
Persentase hasil belajar psikomotor siswa secara klasikal pada siklus 1 sebesar 70\% (lampiran I.3) sedangkan persentase hasil belajar psikomotor siswa secara klasikal pada siklus 2 mencapai 83,3\% (lampiran I.6) dengan demikian dapat diketahui bahwa persentase hasil belajar siswa secara klasikal juga mengalami peningkatan sebesar 13,3\%.

\section{Hasil Wawancara}

Kegiatan wawancara dilakukan sebelum dan setelah penerapan model pembelajaran Interaktif dengan media miniatur. Pelaksanaan wawancara dilakukan terhadap guru dan perwakilan siswa. Wawancara dilakukan berdasarkan lembar pertanyaan yang telah disiapkan sebelumnya. Kegiatan ini dilakukan untuk mengetahui pendapat guru dan siswa sebelum dan setelah diterapkannya model ini.

Berdasarkan hasil wawancara dengan guru sebelum tindakan (lampiran C.1) diketahui bahwa metode yang digunakan guru hanya menggunakan metode ceramah, tanya jawab dan penugasan. Setelah menjelaskan materi dan siswa mencatat materi yang diberikan biasanya guru meminta siswa untuk mengerjakan soal yang ada pada buku LKS, karena penguasaan siswa terhadap materi kurang, siswa sering kesulitan dalam mengerjakan soal.

Untuk hasil wawancara dengan guru setelah tindakan (lampiran C.2) dapat disimpulkan bahwa guru tertarik dengan penerapan model pembelajaran Interaktif dengan media media miniatur yang digunakan dalam tindakan tersebut, karena dengan model dan media tersebut siswa lebih aktif dalam pembelajaran.

Hasil wawancara dengan siswa setelah tindakan (lampiran C.4) menunjukkan bahwa siswa senang terhadap pembelajaran. Hal ini terlihat pada saat pembelajaran, siswa memperhatikan materi pelajaran yang 
dijelaskan, dalam proses belajar mengajar siswa dapat berinteraksi dengan guru dan siswa lain, siswa mampu bekerjasama dalam kelompok dan siswa dapat belajar dengan menggunakan media yang belum pernah digunakan sebelumnya. Suasana belajar yang menyenangkan dan tidak membosankan dapat membuat siswa lebih mudah untuk memahami materi yang diajarkan.

\section{Pembahasan}

Jenis penelitian adalah Penelitian Tindakan Kelas. Penerapan model Interaktif dengan media miniatur bertujuan untuk meningkatkan ketuntasan dan hasil belajar siswa pada materi mengidentifikasi ciri-ciri dan kebutuhan makhluk hidup, sehingga diharapkan di akhir pembelajaran terjadi peningkatan ketuntasan hasil belajar siswa pada materi mengidentifikasi ciri-ciri dan kebutuhan makhluk hidup.

Model Interaktif yang digunakan pada penelitian ini lebih menekankan pada keterampilan bertanya anak dimana model Interaktif ini dirancang agar siswa bertanya dan kemudian menemukan jawaban mereka sendiri. Sehingga dengan penerapan model interaktif siswa lebih aktif dalam kegiatan belajar mengajar dan guru berperan sebagai fasilitator dalam pembelajaran, sedangkan media yang digunakan pada penelitian ini adalah media miniatur makhluk hidup yang terbuat dari plastik, seperti kucing, buaya, gajah, tumbuahan, dll. Media miniatur pada penelitian ini berfungsi untuk mempermudah penyampaian materi mengidentifikasi ciri-ciri dan kebutuhan makhluk hidup dengan penerapan model Interaktif.

Penerapan model Interaktif dengan media miniatur pada pembelajaran IPA materi mengidentifikasi ciri-ciri dan kebutuhan makhluk hidup berjalan dengan baik Ini terlihat pada proses pembelajaran siswa lebih aktif dan antusias mengikuti pembelajaran, 
terjadi interaksi siswa dengan guru dalam proses pembelajaran, siswa dengan siswa dalam kegiatan diskusi kelompok, saling bekerjasama dalam kegiatan kerja kelompok. Berdasarkan hasil analisis data pengamatan yang dilakukan oleh observer selama proses pembelajaran yang dilakukan pada siklus 1 dan siklus 2 maka tujuan model Interaktif dengan media miniatur pada pembelajaran IPA materi mengidentifikasi ciri-ciri dan kebutuhan makhluk hidup dapat tercapai, yaitu dengan meningkatnya hasil belajar dan ketuntasan klasikal siswa dibandingkan dengan hasil belajar dan ketuntasan klasikal siswa saat pembelajaran biasa.

Hasil analisis data dari hasil belajar afektif siswa pada siklus 1 diketahui ketuntasan hasil belajar siswa secara klasikal mencapai 73,3\% dikatakan baik. sedangkan pada siklus 2 diketahui ketuntasan hasil belajar siswa secara klasikal mencapai 86,6\% dikatakan sangat baik.

Hasil analisis data dari hasil belajar psikomotor siswa pada siklus 1 diketahui ketuntasan hasil belajar siswa secara klasikal pada mencapai $70 \%$ dikatakan baik. sedangkan pada siklus 2 diketahui ketuntasan hasil belajar siswa secara klasikal mencapai 83,3\% dikatakan sangat baik.

Hasil analisis data ketuntasan dari hasil belajar kognitif siswa pada siklus 1 belum dikatakan berhasil. Sebab pada pertemuan 1 ketuntasan hasil belajar siswa secara klasikal belum tuntas, yaitu hanya mencapai 66,66\% dengan rincian 20 siswa tuntas dan 10 siswa yang belum tuntas. Oleh karena itu penelitian dilanjutkan pada siklus 2, dari pelaksanaan siklus 2 diperoleh hasil belajar siswa yang cukup memuaskan yaitu 86,66\% (tuntas) dengan rincian 26 siswa yang tuntas dan 4 siswa yang belum tuntas sehingga penelitian tidak dilanjutkan.

Berdasarkan hasil penelitian dan pembahasannya dapat diambil kesimpulan bahwa penggunaan model Interaktif dengan media miniatur pada pembelajaran IPA materi mengidentifikasi ciri-ciri dan kebutuhan makhluk hidup dapat meningkatkan hasil belajar siswa mata pelajaran 
IPA di kelas III SDN Kemuning Lor 02, hal ini dapat dibuktikan dengan adanya peningkatan ketuntasan belajar siswa. Selain itu, juga dapat meningkatkan hasil belajar siswa pada penilaian afektif dan psikomotor, hal ini terbukti ketika pembelajaran siswa merasa senang, semangat, dan aktif

\section{KESIMPULAN}

Berdasarkan hasil penelitian yang telah dilakukan dapat ditarik kesimpulan sebagai berikut:

1) dengan Penerapan model pembelajaran Interaktif dengan media miniatur dapat meningkatkan hasil belajar IPA siswa kelas III SDN Kemuning lor 02 materi mengidentifikasi ciri-ciri dan kebutuhan makhluk hidup. Peningkatan hasil belajar IPA, dapat diketahui dengan hasil yang diperoleh ketuntasan belajar secara klasikal penilaian kognitif pada siklus I mencapai $66,66 \%$ dan pada siklus II mencapai $86,66 \%$ dengan demikian dapat diketahui bahwa presentase hasil belajar siswa secara klasikal juga mengalami peningkatan sebesar $20 \%$, untuk ketuntasan belajar secara klasikal afektif pada siklus I mencapai 73,3\% dan pada siklus II mencapai 86,6\% dengan demikian dapat diketahui bahwa presentase hasil belajar siswa secara klasikal juga mengalami peningkatan sebesar 13,3\%, sedangkan ketuntasan belajar secara klasikal psikomotor pada siklus I mencapai 70\% dan pada siklus II mencapai 83,3\% dengan demikian dapat diketahui bahwa presentase hasil belajar siswa secara klasikal juga mengalami peningkatan sebesar $13,3 \%$.

2) peningkatan hasil belajar siswa juga berpengaruh terhadap peningkatan ketuntasan secara klasikal, diketahui pada penilaian kognitif meningkat sebesar 20\%, untuk penilaian afektif meningkat sebesar $13,3 \%$, sedangkan penilaian psikomotor meningkat sebesar $13,3 \%$. 


\section{Daftar Pustaka}

Abdillah, 2011, Media Pembelajaran dan Jenis-jenisnya. [ Serial Online] , 2011, http:/ / ilmumahasiswa.com/media-pembelajaran-dan-jenisjenisnya/ (diakses tanggal 7 April 2019)

Budiyanto, Arifin, 2014, Pengembangan Media Pembelajaran Pendidikan Agama Islam (PAI) Di SMP Raudlatul Jannah Waru Sidoarjo, tesis, UIN Sunan Ampel Surabaya.

Elvi Sukesih, 2015, Efektivitas Penerapan Model Pembelajaran Berbasis Proyek Terhadap Hasil Belajar Siswa Pada Mata Pelajaran TIK Pokok Bahasan Penggunaan Dasar Internet/Intranet Di SMP N 1 Kaliwungu, Under Graduates thesis, Universitas Negeri Semarang. diakses pada (22 januari 2019)

Isran Rasyid Karo-Karo S dan Rohani, 2018, Manfaat Media Dalam Pembelajaran, Jurnal AXIOM: Vol. VII, No. 1, Universitas Islam Sumatera Utara Medan.

Kusumawati, Frieda Dewi dan Priantari, Ika, 2016, Metode Demonstrasi Dengan Media Tiga Dan Dua Dimensi Terhadap Hasil Belajar Siswa Demonstration Method With Media Three And Two Dimensional Through Student Achievement, Jurnal Pendidikan Biologi FKIP Universitas Muhammadiyah Jember.

Meliana, Wijayanti, 2012 Pengembangan Media Pembelajaran Membaca Titi Laras Tembang Macapat Dhandhanggula Menggunakan Aplikasi Adobe Flash CS5 Untuk Siswa Smp Kelas Viii, tesis, Universitas Negeri Yogyakarta.

Nurfadillah, Arsyi, 2018, Penggunaan Media Komik Untuk Meningkatkan Keterampilan Berkomunikasi Dan Hasil Belajar Siswa Kelas IV Tema Indahnya Kebersamaan Subtema Keberagaman Budaya Bangsaku, thesis, FKIP UNPAS. http://repository.unpas.ac.id/39513/

Normawati, Feni, 2016, Meningkatkan Keaktifan Peserta Didik dalam Proses Pembelajaran Dengan Menggunakan Model Pembelajaran Make A Match (Membuat Pasangan). skripsi, FKIP UNPAS, http://repository.unpas.ac.id/11297/(diakses pada 12 Januari 2019)

Pontiani, Nining, 2015, Penerapan Metode Make A Match Untuk Meningkatkan Hasil Belajar Ilmu Pengetahuan Sosial (Ips) Siswa Kelas Iii Mi Tarbiyatul Banin Walbanat Kedungsigit Karangan 
Trenggalek, Fakultas Tarbiyah Dan Ilmu Keguruan Institut Agama Islam Negeri (Iain) Tulungagung.

Rusman, 2017, Belajar E Pembelajaran: Berorientasi Standar Proses Pendidikan, Jakarta:Kencana.

Rusydiyah, Evi Fatimatur., 2015,Media Pembelajaran (Implementasi untuk Anak di Madrasah Ibtidaiyah), UIN Sunan Ampel Surabaya.

Roestiyah, N.K. 1994, Masalah Pengajaran sebagai Suatu Sistem. Jakarta : PT Rieneka Cipta.

Sangadah, Novitangatus., 2019, Pengaruh Model Pembelajaran Active Learning Tipe Card Sort Terhadap Hasil Belajar Fiqih Siswa Kelas Viii Di MTSN 2 Tulungagung, Skripsi, IAIN Tulungagung, http://repo.iain-tulungagung.ac.id/12733/ diakses pada (22 januari 2019)

Sulastri, 2015, Meningkatkan Prestasi Belajar Siswa Melalui Model Pembelajaran Interaktif Pada Pokok Bahasan Konduktor Dan Isolator, Jurnal Serambi Ilmu, Volume 22 Nomor 1. Universitas Serambi Mekkah.

Sutrisno. 2008, Pengembangan Pembelajaran IPA SD (Diktat Kuliah). Jakarta :Universitas terbuka.

Tri Karyanti, dkk. 2019, Pendidikan Anti Korupsi Berbasis Multimedia, Yogyakarta:Deepublish.

Umar, 2014, Media Pendidikan: Peran dan Fungsinya dalam Pembelajaran, Jurnal Tarbawiyah Volume 11 Nomor 1, IAIN Metro.

West \& Pines dan Sutarno, N. 2009, Materi dan Pembelajaran IPA SD. Jakarta: Universitas Terbuka.

Zainiyati, Husniyatus Salamah, 2017, Pengembangan Media Pembelajaran Agama Islam Berbasis ICT, Jakarta:Penerbit Kencana.

https://kbbi.kemdikbud.go.id/ 
Bayu Widiyanto

68 | Bidayatuna, Vol. 03 No. 01 April 2020 